\title{
Isotopic analysis of the ecology of herbivores and carnivores from the Middle Pleistocene deposits of the Sierra De Atapuerca, northern Spain
}

\author{
N. García García ${ }^{\mathrm{a}, \mathrm{b}, *}$, R.S. Feranec ${ }^{\mathrm{c}, *}$, J.L. Arsuaga ${ }^{\mathrm{a}, \mathrm{b}}$, J.M. Bermúdez de Castro ${ }^{\mathrm{d}}$, E. Carbonell ${ }^{\mathrm{e}}$ \\ ${ }^{a}$ Departamento de Paleontologia, Facultad de Ciencias Geológicas, Universidad Complutense de Madrid, Ciudad Universitaria, 28040 Madrid, Spain \\ ${ }^{\mathrm{b}}$ Centro Mixto (UCM-ISCII) de Evolución y Comportamiento Humanos, C/Sinesio Delgado 4, Pab. 14, 29029 Madrid, Spain \\ ${ }^{c}$ New York State Museum, 3140 Cultural Education Center, Albany, NY 12230, USA \\ ${ }^{\mathrm{d} C e n t r o ~ N a c i o n a l ~ d e ~ I n v e s t i g a c i o ́ n ~ s o b r e ~ l a ~ E v o l u c i o ́ n ~ H u m a n a ~-~ C E N I E H, ~ A v d a ~ d e ~ L a ~ P a z, ~ 28, ~ 09004 ~ B u r g o s, ~ S p a i n ~}$ \\ ${ }^{e}$ Institut Català de Paleoecologia Humana i Evolució Social (IPHES), C/ Escorzador, s/n 43003 Tarragona, Spain
}

Keywords:

C-13

Diet

Ecology

Enamel

Mammal

$0-18$

Pleistocene

\begin{abstract}
A B S T R A C T
Carbon and oxygen isotope values reveal resource partitioning among the large mammal fauna from three contemporaneous Middle Pleistocene hominid-bearing localities within the Sierra de Atapuerca (northern Spain). Carbon isotope values sampled from the tooth enamel of fauna present during Atapuerca Faunal Unit 6 show that a $C_{3}$-dominated ecosystem surrounded the area where fossils were preserved during this time. For the herbivores, Fallow deer isotope values are significantly different from Red deer and horses and show that this species did not forage in open environments at this locality. Red deer and horses show similar feeding strategies with less negative carbon values implying use of more open environments for these taxa. For the carnivores, carbon isotope values for Ursus deningeri are significantly different from either lions (Panthera leo) or foxes (Vulpes vulpes) and support the contention that this species is herbivorous. Special metabolic mechanisms involved in hibernation in $U$. deningeri might also have influenced its isotope values. The carbon isotope values of remaining carnivores were similar and suggest that each was typically a generalist carnivore, eating a wide variety of prey items. While the isotopic results generally correspond to ecology indicated by previous techniques, this study shows that isotope analyses can provide further insights that alternate techniques do not provide. Isotope analyses can help elucidate the ancient ecology of taxa present in the Sierra de Atapuerca during the Middle Pleistocene allowing for an accurate portrayal of the setting in which humans lived.
\end{abstract}

\section{Introduction}

The fossil deposits in the Sierra de Atapuerca of northern Spain (Fig. 1) have become well known due to the discovery of sustained presence of humans over more than the last one million years of the Pleistocene. Besides human remains and artifacts (Arsuaga et al., 1993, 2001; Bermúdez de Castro et al., 1997; Carbonell et al., 1995, 2001), abundant faunal remains have been recovered (CuencaBescós and Conesa, 1997; García et al., 1997; García and Arsuaga, 1998, 1999, 2001b; van der Made, 1999, 2001; Cuenca-Bescós et al., 2001), providing the opportunity to examine community ecology through time (Rodríguez, 1997; López Antoñanzas and CuencaBescós, 2002; García and Virgós, 2007), and attempt to understand

\footnotetext{
* Corresponding authors. Tel.: +1 518474 5819; fax: +1 5184862034.

E-mail addresses: ngarcia@isciii.es (N. García García), rferanec@mail.nysed.gov (R.S. Feranec), jlarsuaga@isciii.es (J.L. Arsuaga), jm.ber@cenieh.es (J.M. Bermúdez de Castro), eudald.carbonell@urv.cat (E. Carbonell).
}

the context in which humans lived over the time represented by the Middle Pleistocene deposits (Falguères et al., 1999; Bischoff et al., 2007) here analyzed.

One technique that has proven useful to examine faunal ecology in ancient mammals is through examination of stable isotope values found in tooth enamel (Quade et al., 1992; Bocherens et al., 1996; MacFadden and Cerling, 1996; Cerling et al., 1998; Koch et al., 1998; Bocherens, 2003; Drucker et al., 2003; Kohn et al., 2005). Isotopic analyses can reveal information about resource use and resource partitioning among fauna, being able to determine diet and habitat use, for example. While these analyses have concentrated on examining herbivorous taxa where there is a mixture of plants using the $C_{3}$ or $C_{4}$ photosynthetic pathways (DeNiro and Epstein, 1978a; Vogel, 1978; MacFadden and Cerling, 1996; Cerling et al., 1997; Koch et al., 1998), recent studies have shown resource use and partitioning among ancient carnivores as well as in areas containing only $\mathrm{C}_{3}$ plants (Bocherens et al., 1996, 2004; Bocherens, 2003; Cerling et al., 2004; Kohn et al., 2005; Feranec and MacFadden, 2006). 


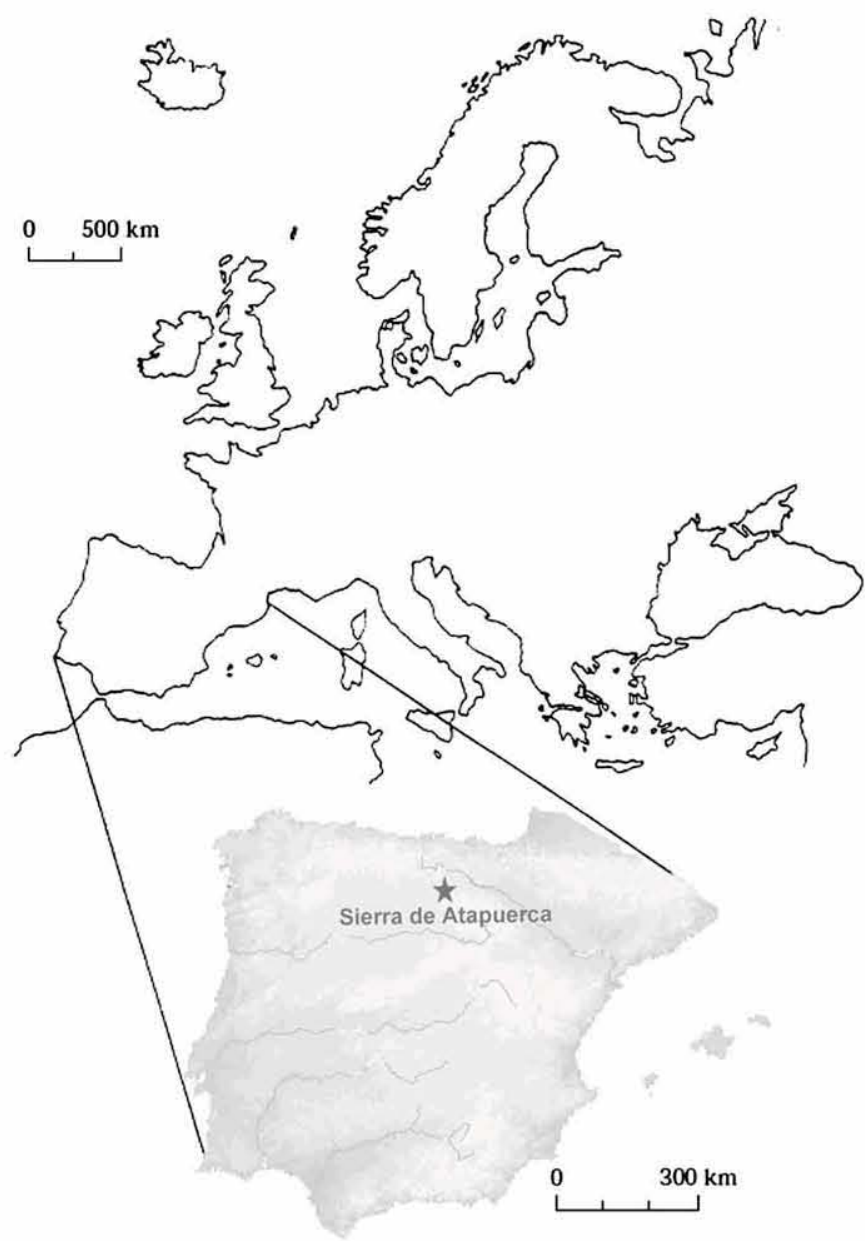

Fig. 1. Location of Sierra de Atapuerca complex of sites in northern Spain.

This study analyzes stable carbon and oxygen isotope values found in the tooth enamel of mammalian carnivores and herbivores with the overall aim of understanding the ecological context in which the ancestors of Neanderthals lived within the Sierra de Atapuerca during the Middle Pleistocene. We will address: (1) whether stable isotope values permit identification of resource use and partitioning among taxa? (2) If resource use and partitioning are determined, do the results corroborate the ecology predicted by other methodologies (e.g. morphology, comparison to extant species, and biometry)? We examine whether stable isotope analyses will provide another technique to better understand ancient ecology in the Sierra de Atapuerca which will enable an accurate portrayal of the setting in which humans lived.

\section{Background}

\subsection{Locality correlation}

The three archeo-paleontological sites from Sierra de Atapuerca included in this study can be divided into the Trinchera del Ferrocarril sites and the Sima de los Huesos site in the Cueva Mayor Cueva del Silo karst complex (Fig. 2). The Trinchera del Ferrocarril includes the two sites: Trinchera Galería (TG) and Trinchera Dolina (TD). TD and TG have yielded fossil human remains, fauna, and lithic industries that range from the late Early Pleistocene to the Middle Pleistocene. However, for correlation reasons, this study only analyzes the faunas coming from the Middle Pleistocene layers of these two sites: Units GII and GIII of TG and levels TD10 and TD11 of TD. The Sima de los Huesos (SH) lies inside Cueva Mayor, and contains an extraordinary accumulation of a set of approximately thirty human individuals (Homo heidelbergensis) in an ancient mud-breccia, together with an assemblage of carnivores, especially bears (García et al., 1997; García, 2003) and scarce rodents and insectivores (Cuenca-Bescós and Conesa, 1997; Cuenca-Bescós et al., 2001).

The TG complex and TD are not currently connected to the Cueva Mayor - Cueva del Silo caves. SH has been dated to around 530 ka B.P. (Bischoff et al., 2007), while TGII-III and TD10-11 might be slightly younger, around 400 ka (Falguères et al., 1999; Berger et al., 2008) (Fig. 3). Even so, the three associations are referred to the same Faunal Unit (FU) (Cuenca-Bescós and García, 2007) and are characterized by the presence and/or absence of particular mammalian taxa. The three deposits share small (Arvicola sp., Pliomys lenki, Clethrionomys cf. glareolus, Microtus (Terricola) atapuerquensis, Microtus (Microtus) arvalis, Microtus (Agricola) agrestis) (Cuenca-Bescós et al., 2001) and large (Dama dama clactoniana, Cervus elaphus priscus, Equus sp. (caballine-type), Hemitragus bonali, Panthera leo cf. fossilis, Vulpes vulpes, Meles meles) mammals. Also, four horse teeth sampled for this study come from TD level 10, and were the same specimens sampled by ESR analysis providing a mean age of $372 \pm 33 \mathrm{ka}$ (Falguères et al., 1999) The fauna included in this study are placed within ATA FU 6 (Cuenca-Bescós and Garcia, 2007), which is characterized by the presence of Terricola atapuerquensis, Iberomys brecciensis and Allocricetus correzensis (Cuenca-Bescós and García, 2007). ATA FU 6 is also represented by the presence of the caballine horses (Equus caballus ssp.), Stephanorhinus cf. hemitoechus, D. dama clactoniana and $H$. bonali. The first appearance of true wolves (Canis lupus) at Atapuerca also occurs within this faunal unit at GIII of TG. Similarly, the first appearance of $P$. leo at Atapuerca could be either at the base of TD10 or at TG or SH. This faunal unit likely represents the period of expansion of lions in Europe since they disperse into the continent from Africa in the Early Middle Pleistocene by their first occurrence at Isernia La Pineta (Italy) (García, 2003) dated by ${ }^{40} \mathrm{Ar} /{ }^{39} \mathrm{Ar}$ to $605 \mathrm{ka}$ (Coltorti et al., 2005). Although the fauna from these three localities may have lived at different times, we suspect the ecological relationship among mammals within ATA FU 6 to have remained the same over time.

\subsection{Faunal ecology and isotopic predictions}

For many of the taxa sampled within this study morphology has not changed significantly since the Middle Pleistocene. To get a better understanding of the ecology of these more ancient populations, we review the dietary preferences of the extant species with the aim of more accurately identifying the paleoecology of fauna present during the Pleistocene around the Sierra de Atapuerca.

\subsection{Herbivores}

Cervids: Cervus elaphus (Red deer) is classified as an intermediate feeder by Hofmann $(1985,1989)$, and therefore is capable of feeding on a wide variety of forage including grasses, sedges and concentrate foods (e. g. leaves of trees and shrubs). More specifically, Gebert and Verheyden-Tixier (2001), identified the food resources of European $C$. elaphus and similarly concluded that they eat a wide range of plant species and select a mixed diet with four principal plant groups: grass and sedges $(\sim 30 \%$, a very constant resource), Calluna and Vaccinium (heath family) $(\sim 23 \%$, principally in moorland from Scotland), leaves of deciduous trees and shrubs ( $\sim 10 \%$, principally in mixed-deciduous forests) and conifers ( $\sim 9 \%$, 


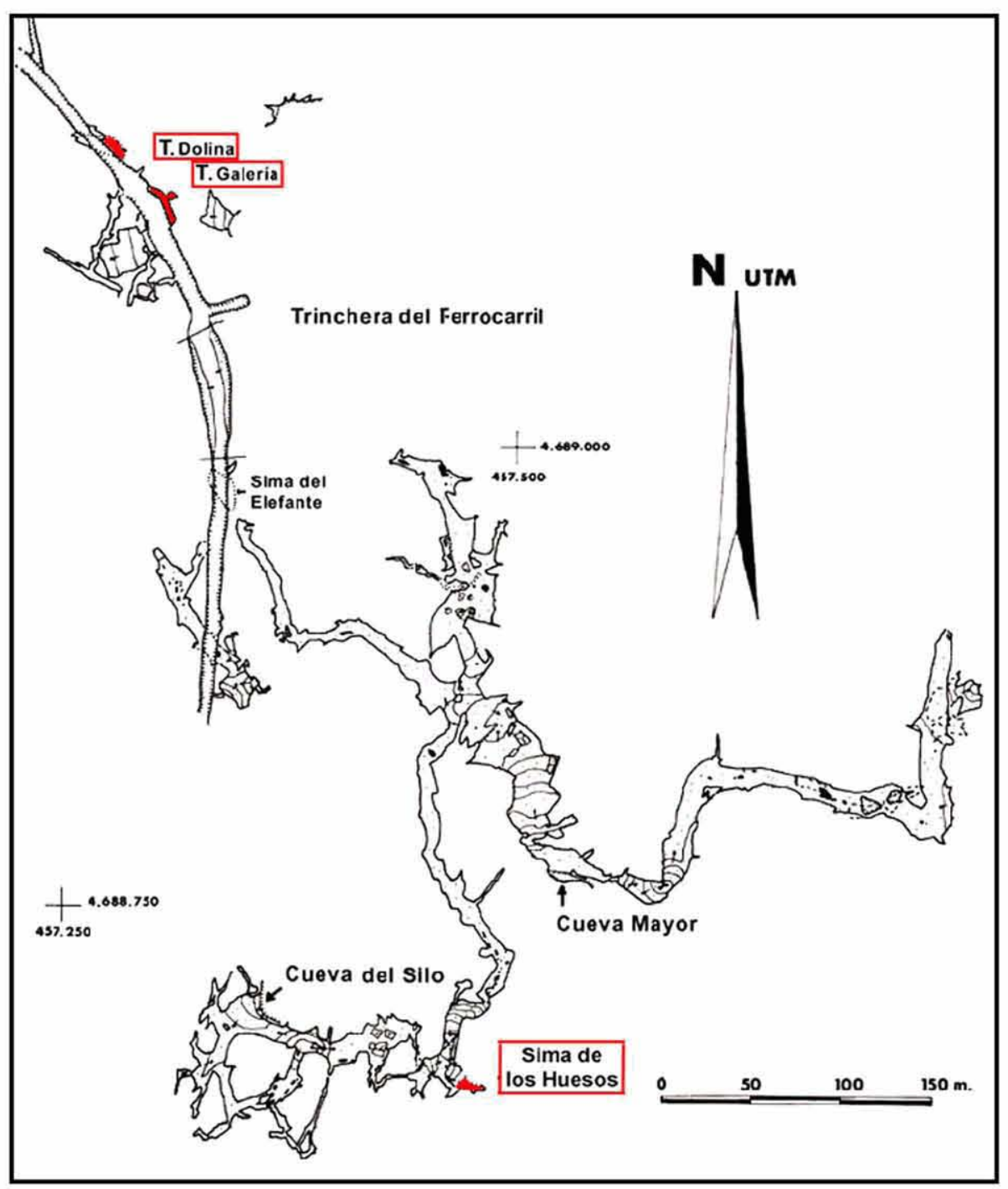

Fig. 2. Plan of the Sierra de Atapuerca cave systems (by G. E. Edelweiss).

in forests, particularly during winter and spring). When these mean percentages were analyzed in detail, it was evident that environmental factors, such as type of habitat and season affect the composition of European $C$ elaphus diet. For these cervids, it was only grasses and sedges that did not show any significant variation in consumption among habitats, seasons, or sexes, and generally always occurred at a relatively constant level. For the ancient $C$. elaphus, we predict carbon isotope values typical of an intermediate

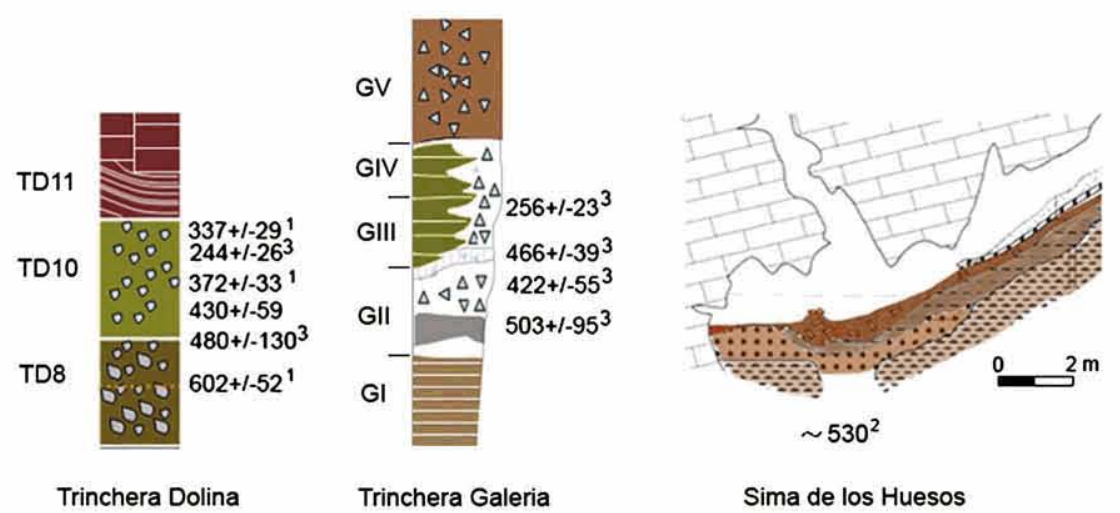

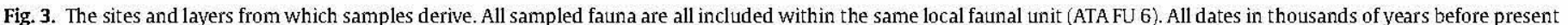
(ka). ${ }^{1}$ Dates from Falguères et al. (1999). ${ }^{2}$ Dates from Bischoff et al. (2007). ${ }^{3}$ Dates from Berger et al. (2008). 
feeding herbivore with some individuals showing consumption of grasses in open habitats.

The present ecology of Fallow deer, D. dama, suggests that this species is well adapted to a wide range of different habitats in Europe. However, the origin of its modern generalized ecological ability might be the result of a high degree of environmental patchiness found in its post-glacial Near East range. It was from this range that the species was introduced to most of Europe (Apollonio et al., 1998). In present-day Spain, D. dama inhabiting Sierra de Cazorla, a Mediterranean habitat with evergreen Quercus, have a strong preference for grasses (García-González and Cuartas, 1992) although this population also consumes Quercus rotundifolia, Phillyrea latifolia, Rosmarinus officinalis, Oryzopsis paradoxa and Festuca arundinacea (Martínez Martínez, 2002). While grasses appear to be the dominant food for modern populations, $D$. dama have been known to consume a large proportion of browse, including fruit, during winter (Chapman and Chapman, 1975; Putnam, 1988). The 300-400 ka faunal assemblages at Quesem cave (Israel) (Barkai et al., 2003) display a high predominance of Fallow deer roughly correlative to the time period of the faunas analyzed here at Atapuerca. This suggests that D. dama was also a successful inhabitant of Mediterranean dry environments, at least during the Middle Pleistocene. Consumption of grasses would suggest competition with $C$. elaphus, while browsing implies a higher degree of resource partitioning between these deer species. During the Middle and Late Pleistocene, Dama clactoniana and D. dama have been identified at many sites, generally in temperate faunal associations (Kurtén, 1968; Leonardi and Petronio, 1976). Based on this, D. dama is suspected to inhabit open woodland and forest, being found mostly amongst woodland glades and openings. More studies of $D$. dama are needed, especially in mixed-deciduous and/or evergreen forest habitats, in order to get a better understanding of its ecology, today and in the Pleistocene. Even so, based on what we know of their modern and suspected ancient ecology (Bocherens et al., 1999; Geist, 1999), we predict that isotope values will be similar to C. elaphus showing the capability of feeding on an intermediate diet but having a strong preference for grasses and more open habitats. Isotopically, we would predict that $D$. dama would have values slightly more positive than $C$. elaphus indicative of preference of feeding on grasses.

Equids: The interpretation of ecology in ancient horse taxa differs based on their functional anatomy. The Caballine group, which first appeared in Europe at Mosbach, are typically characterized by larger molars and generally more massive extremities. This is in comparison to the smaller Hemionines, which are thought to inhabit more open and arid regions as modern Asian representatives. The Equus sp. teeth sampled here all belong to the Caballine clade (van der Made et al., 2003), and based on modern ecology and prior studies on ancient horses (MacFadden et al., 1999; Kaiser and Franz-Odendaal, 2004; Stevens and Hedges, 2004), we predict that the analyzed horses are intermediate feeders, foraging grasses as well as tree and shrub foliage where and when available. Further, we hypothesize that they would be more similar isotopically to $C$. elaphus than to D. dama at this fossil locality.

\subsection{Carnivores}

Ursids: One unique carnivore represented in the deposits of the Sierra de Atapuerca is Ursus deningeri. $U$. deningeri is the forerunner of the well-known Late Pleistocene cave bear, Ursus spelaeus, and is the most common bear species represented during the Middle Pleistocene in Europe. These two chronospecies, constituting part of the cave bear lineage, have a presumed hyper-specialization towards vegetarianism. While the phylogenetic relationship between the two cave bear species has been largely demonstrated by many morphological studies (Torres, 1984; Tsoukala, 1989; Mazza and Rustioni, 1994; Mazza et al., 1995; García et al., 1997; García, 2003) and recently through ancient DNA analyses (Valdiosera et al., 2006), the degree of vegetarianism in the ancestral $U$. deningeri, remains unexplored. Dental and cranial adaptations observed in $U$. spelaeus indicate an almost exclusively vegetarian habit (Soergel, 1926; Erdbrink, 1953; Thenius, 1965; Kurtén, 1968) and recent isotopic studies support this conclusion (Bocherens et al., 1991a, 1994). One of our primary aims will be to focus on the ecology of $U$. deningeri to better understand their evolution and the transition from the ancestral U. deningeri to descendent $U$. spelaeus.

The teeth of $U$. deningeri appear to be morphologically intermediate between Ursus dolinensis, the most primitive representative of the cave bear lineage whose dentition resembles Ursus arctos, and U. spelaeus, whose teeth are much broader (García and Arsuaga, 2001a, b). This implies that although the diet might not be exclusively vegetarian (as in U. spelaeus), the dental anatomy is more similar to the "herbivorous" cave bears than to those of the more carnivorous brown bears (Mazza and Rustioni, 1994; García, 2003). Isotopic analyses should help elucidate this dietary ecology further. Based on previous carbon isotope analyses of bears (Bocherens et al., 1991a, 1994, 1997; Nelson et al., 1998), we predict the isotope values to be more negative than the other carnivores.

Canids: The Middle Pleistocene wolf from Atapuerca is considered a "true wolf" based on morphology even though morphological dimensions have not reached the slightly larger size of the modern Holarctic species, $C$. lupus. For the Atapuerca wolf, we presume a generalist-carnivore diet, with isotope values generally falling among the large herbivore (prey) values, similar to what modern wolves eat today in the wild (Mech, 1974). The dhole, Cuon alpinus, is known to primarily hunt and eat large mammals, although smaller mammals will be taken on occasion (Cohen, 1978). Due to the lack of the lower third molar, dholes are generally thought to be more carnivorous than wolves or foxes (Garcia and Arsuaga, 1998). Similar to the other canids, the red fox, V. vulpes, is a generalist carnivore, but in contrast to the other sampled canids, the fox is known to take a large proportion of small mammals as prey as opposed to large mammals (Lariviere and Pasitschniak-Arts, 1996). Scavenging as well as consumption of various plant matter and invertebrates is not uncommon (Lariviere and PasitschniakArts, 1996). Based on known canid diets, we would predict to observe carbon isotope values intermediate among the various prey for the sampled Atapuerca canids.

Felids: Modern Lynx spp. are strictly carnivorous and typically consume lagomorphs and other small mammals as their primary prey although larger prey (e.g., Roe deer) can be taken on occasion (Tumlison, 1987; Lariviere and Walton, 1997). Lions, P. leo, are opportunistic predators, and while they may occasionally hunt and consume small prey such as rodents, fish or even termites, they typically prey on large mammals (Haas et al., 2005). Isotopically, we would expect to find lion values similar to those of the large canids, intermediate among the sampled herbivores. We would expect the Lynx isotope values to be similar to the red fox, both being consumers of similar small prey.

\subsection{Isotopes in Paleoecology}

Isotopic results in this study are expressed in the standard $\delta$ notation: $X=\left[\left(R_{\text {sample }} / R_{\text {standard }}\right)-1\right] \times 1000$, where $X$ is the $\delta^{13} \mathrm{C}$ or $\delta^{18} \mathrm{O}$ value, and $R={ }^{13} \mathrm{C} /{ }^{12} \mathrm{C}$ and ${ }^{18} \mathrm{O} /{ }^{16} \mathrm{O}$, respectively. The $\delta^{13} \mathrm{C}$ and $\delta^{18} \mathrm{O}$ values are reported relative to the V-PDB standard.

Animals that feed on different kinds of plants will reflect the carbon isotope value of their food in their tissues (DeNiro and Epstein, 1978b; Vogel, 1978; Tieszen et al., 1979). Carbon isotope values are useful in diet studies because the three different 
photosynthetic pathways used by plants, $\mathrm{C}_{3}, \mathrm{C}_{4}$, and Crassulacean Acid Metabolism (CAM), impart different ${ }^{13} \mathrm{C} /{ }^{12} \mathrm{C}$ ratios to plant tissues. Tropical, warm-growing-season grasses and sedges using the $\mathrm{C}_{4}$, or Hatch-Slack, photosynthetic pathway are relatively enriched in the heavy carbon isotope $\left({ }^{13} \mathrm{C}\right)$. These plants have a mean $\delta^{13} \mathrm{C}$ value of $-13.0 \%$ and generally range from $-9 \%$ to $-19 \%$ (O'Leary, 1988; Farquhar et al., 1989; Ehleringer et al., 1991; Ehleringer and Monson, 1993). On the other hand, $\mathrm{C}_{3}$, or Calvin cycle, plants including most trees and shrubs, as well as grasses in regions with cool growing seasons, are relatively enriched in the light carbon isotope $\left({ }^{12} \mathrm{C}\right) . \mathrm{C}_{3}$ plants have a mean $\delta^{13} \mathrm{C}$ value of $-27.0 \%$ and typically range from $-22 \%$ to $-35 \%$ (O'Leary, 1988; Farquhar et al., 1989; Ehleringer et al., 1991; Ehleringer and Monson, 1993). The third pathway, the Crassulacean Acid Metabolism (CAM) pathway, is characteristic of succulents (e.g. cacti) and may yield values that range between the end members for $C_{3}$ and $C_{4}$ plants (O'Leary, 1988; Ehleringer et al., 1991; Ehleringer and Monson, 1993). CAM photosynthesis is typically found in more restricted xeric habitats, CAM plants are generally not widespread on the landscape (Ehleringer et al., 1991), and very few extant large ungulates use succulents as a significant part of their diet (Janis and Ehrhardt, 1988). Therefore, it is assumed that the herbivores in this study did not make succulents a significant part of their diet, and the isotopic effects of CAM photosynthesis are not considered in this study.

Studies utilizing differences in the carbon isotope values from mammals generally focus on communities containing a mixture of $C_{3}$ and $C_{4}$ plants, which enables taxa to be distinguished based on the predominant forage included in the diet (Vogel, 1978; Tieszen, 1994; MacFadden and Cerling, 1996; Cerling et al., 1998; Koch et al., 1998; Kohn et al., 2005). Based on previous studies and where the fossil localities are situated, it is predicted that the flora during the late Pleistocene in the Sierra de Atapuerca was dominated by $\mathrm{C}_{3}$ plants (Flynn et al., 1984; Collins and Jones, 1985; Sage et al., 1999; Pamlqvist et al., 2003). Different processes, however, such as variation in light intensity, temperature, nutrient availability, and water stress, can produce variation in the $\delta^{13} \mathrm{C}$ value in $\mathrm{C}_{3}$ plants (Farquhar et al., 1989; O'Leary et al., 1992; Ehleringer and Monson, 1993; Koch, 1998; Heaton, 1999; Bocherens, 2003). $C_{3}$ plants typically have more negative values in closed, forested habitats; while in more open, drier habitats more positive isotope values are typical (Farquhar et al., 1989; van der Merwe and Medina, 1991; O'Leary et al., 1992; Ehleringer and Monson, 1993; Heaton, 1999; Bocherens, 2003; Cerling et al., 2004). Recent studies have used these habitat differences to highlight the use of carbon isotopes in determining resource partitioning of herbivores in $\mathrm{C}_{3}$-dominated environments (Quade and Cerling, 1995; Bocherens et al., 1997, 2001; Cerling et al., 1999, 2004; Bocherens, 2003; Drucker et al., 2003; Feranec and MacFadden, 2006).

\subsection{Stable carbon isotope values in mammalian herbivores}

Herbivores reflect the carbon isotope values of plants ingested, but the $\delta^{13} \mathrm{C}$ value of the tooth enamel is further enriched by a consistent amount, about $+14.0 \%$ for medium- to large-bodied mammals (Cerling and Harris, 1999; Passey et al., 2005). Setting the fractionation from plant material to tooth enamel at $+14.0 \%$ o extant taxa that feed solely on $\mathrm{C}_{3}$ plants will display enamel carbon isotope values between $-21.0 \%$ and $-8.0 \%$. Modern taxa that feed solely on $\mathrm{C}_{4}$ plants exhibit enamel $\delta^{13} \mathrm{C}$ values around $0.0 \%$ (Koch, 1998; Passey et al., 2005). The carbon in plants and ultimately enamel is derived from the atmosphere. The $\delta^{13} \mathrm{C}$ value of atmospheric $\mathrm{CO}_{2}$ has decreased $-1.5 \%$, from $-6.5 \%$, to about $-8.0 \%$, due to fossil fuel burning over the last 200 years (Friedli et al., 1986; Marino and McElroy, 1991; Marino et al., 1992). A diet of pure $C_{3}$ plants would range from $-19.5 \%$ to $-6.5 \%$ in the enamel of Pleistocene herbivores. Isotope values more positive than $-6.5 \%$ would imply incorporation of either $\mathrm{C}_{4}$ or CAM plants into the diet. The $-6.5 \% \delta^{13} \mathrm{C}$ value as indicative of $\mathrm{C}_{4}$ or CAM plant incorporation into an herbivore diet appears very conservative as previous studies on modern and fossil herbivores show that pure $C_{3}$ feeders rarely have values more positive than $-8.0 \%$ (MacFadden and Cerling, 1996; Cerling et al., 1999, 2004).

\subsection{Carbon isotopes in mammalian carnivores}

Similar to the herbivores, carnivore carbon isotope values within tooth enamel derive from the isotopic value of their prey. Based on the portion of prey ingested (e.g. muscle, organs), and the fractionation of isotopic values between the food and the tooth enamel, carnivores typically display tooth enamel carbon isotope values slightly more negative than the tooth enamel of their prey (Bocherens et al., 1994; Grocke, 1997; Lee-Thorp et al., 2000; Bocherens, 2000; Kohn et al., 2005; Fox-Dobbs et al., 2006). FoxDobbs et al. (2006) show a mean $\delta^{13} \mathrm{C}$ difference from prey tooth enamel to predator tooth enamel of $-1.3 \%$.

\subsection{Oxygen isotopes in mammals}

The oxygen isotopes in mammal tooth enamel depend on the isotopic composition of ingested water, the consistent fractionation of oxygen isotopes between body water and the tooth enamel, and the metabolism of the particular animal (Land et al., 1980; Longinelli, 1984; Luz et al., 1984; Luz and Kolodny, 1985; Koch et al., 1989; Kohn, 1996; Kohn et al., 1996, 1998). Mammals ingest water from two sources, either through drinking meteoric water or from what they consume. Meteoric water is affected by climatic influences such as temperature and humidity, such that $\delta^{18} \mathrm{O}$ values are more positive where and when it is warmer and more negative where and when it is colder (Dansgaard et al., 1982; Rozanski et al., 1992; Fricke and O'Neil, 1996; Kohn and Welker, 2005). Because all the sampled species are located within the same general area at the same time, the isotopic values of ingested meteoric waters are assumed to be similar. For the herbivores, water in plant leaves also varies and is typically more positive than the local meteoric waters due to evapotranspiration. Enrichment in $\delta^{18} \mathrm{O}$ values in the leaves is more pronounced in warmer and more arid conditions (Yakir et al., 1990; Yakir, 1992; Ometto et al., 2005). Thus, animals that occupy open habitats would be expected to ingest more positive $\delta{ }^{18} \mathrm{O}$ as compared to taxa foraging in a cooler, moister forested habitat.

Body size and metabolism can also influence the oxygen isotope composition in tooth enamel. Large mammals that are obligate drinkers and tend to have lower metabolisms are most likely to track $\delta^{18} \mathrm{O}$ values of ingested waters (Longinelli, 1984; Luz et al., 1984; Bryant and Froelich, 1995). All species analyzed within this study are large and considered to have a lower metabolism. However, because it is not possible to know whether the ancient taxa studied were obligate drinkers or to know the metabolism of each individual, the $\delta{ }^{18} \mathrm{O}$ values are scrutinized with caution. Where appropriate, we will also make comparisons to a species' modern ecology and whether they are currently drinkers or capable of obtaining enough water from alternate sources (e.g., vegetation).

\section{Materials and methods}

Tooth enamel of a total of 58 specimens from nine species, representing the most abundant species in the assemblages, from the Middle Pleistocene deposits of the Sierra de Atapuerca was 
sampled. The three herbivore species analyzed include $C$ elaphus priscus, D. dama clactoniana, and Equus sp. caballine-type. Six carnivore species were also sampled and include $C$. lupus, C. alpinus, Lynx pardinus spelaeus, P. leo, U. deningeri, and V. vulpes. Because our goal was to recognize the resource partitioning in adult animals, preference was given to sampling teeth that are among the last ones to develop, mineralize, and erupt (Linhart, 1968; Slaughter et al., 1974; Smuts et al., 1978). While preference was given to the teeth developing last, these were sometimes not available and alternative teeth were sampled.

The general method for stable isotope sampling of tooth enamel followed MacFadden and Cerling (1996) and Koch et al. (1997). For the tooth enamel, sampling involved drilling about $10-20 \mathrm{mg}$ of pristine enamel powder off the tooth along a non-occlusal surface parallel to the growth axis and across its entire length using a $0.5 \mathrm{~mm}$ inverted cone carbide drill bit and a variable speed Dremel ${ }^{\mathrm{TM}}$ rotary tool. The powder was first collected and treated with $30 \%$ hydrogen peroxide for $24 \mathrm{~h}$ to remove organics. The hydrogen peroxide was then decanted and the enamel powder was then washed with distilled water, and soaked in $0.1 \mathrm{~N}$ acetic acid for another $24 \mathrm{~h}$ to remove any diagenetic carbonate. The following day the acetic acid was decanted and the enamel powder was washed with distilled water and dried.

After treatment, the samples were analyzed using an ISOCARB automated carbonate preparation system attached to a Micromass Optima gas source mass spectrometer within the Geology Department at the University of California, Davis. The $\sim 1 \mathrm{mg}$ samples were dissolved in $100 \%$ phosphoric acid at $90^{\circ} \mathrm{C}$ to create $\mathrm{CO}_{2}$. All samples were corrected to NBS-19 and UCD-SM92 an inhouse marble standard. Precision for the samples was $0.1 \%$ for both carbon and oxygen.

Mean differences among species within localities were compared by ANOVA and post hoc Tukey HSD tests. Tukey HSD tests are similar to $t$-tests but take into account multiple comparisons. Statistical analyses were run on JMP IN 5 for students, with significance set at $p<0.05$.

\section{Results}

Significant differences are observed in both carbon and oxygen isotope values among the three herbivore species (Appendix 1), forming two distinct groups (Fig. 4). All samples had carbon isotope $\left(\delta^{13} \mathrm{C}\right)$ values more negative than $-10.0 \%$ indicating a habitat dominated by $C_{3}$ plants, similar to modern ecosystems in Spain (Collins and Jones, 1985). C. elaphus and Equus sp. form a separate group from $D$. dama. The mean carbon isotope values for $C$ elaphus $\left(-11.4 \%_{o} \pm 0.7 \% ; n=7\right)$ and Equus sp. $(-11.4 \% \pm 0.5 \% ; n=4)$ are the same, while the value for D. dama $(-13.7 \%, \pm 0.3 \% ; n=2)$ is more negative (Table 1 ). Opposite the carbon isotope results, the mean oxygen isotope $\left(\delta^{18} \mathrm{O}\right)$ values for $D$. dama are the most positive for the herbivores $(-4.7 \% \pm 0.4 \%$, while the mean values for C. elaphus $\left(-8.4 \%_{0} \pm 1.3 \%\right)$ and Equus sp. caballine-type $(-9.1 \% \pm 1.7 \%)$ are more negative.

Significant differences are also observed in $\delta^{13} \mathrm{C}$ and $\delta^{18} \mathrm{O}$ values among the six carnivore species (Appendix 1). For carbon, $U$. deningeri has the most negative mean $\delta^{13} \mathrm{C}$ value $(-15.2 \% \pm 1.1 \%$; $n=23)$ and is significantly different from P. leo $(-13.2 \% \pm 0.4 \%$; $n=6)$ and $V$. vulpes $(-12.2 \% \pm 0.8 \% ; n=12)$. All other taxa are statistically similar. Displaying the most positive mean $\delta^{13} \mathrm{C}$ value for the carnivores was C. Iupus ( $n=1$ ) with a value of $-12.1 \%$ (Table $1)$. For oxygen, $V$. vulpes had the most positive mean $\delta{ }^{18} \mathrm{O}$ value at $-4.8 \% \pm 1.0 \%$ and was significantly different from all taxa except C. Iupus. C. lupus is significantly different from U. deningeri and P. leo. L. p. spelaeus $(-7.9 \% \pm 0.3 \% ; n=2)$ and C. alpinus $(-8.1 \% \circ n=1)$ are similar to all taxa except $V$. vulpes. Displaying the most negative
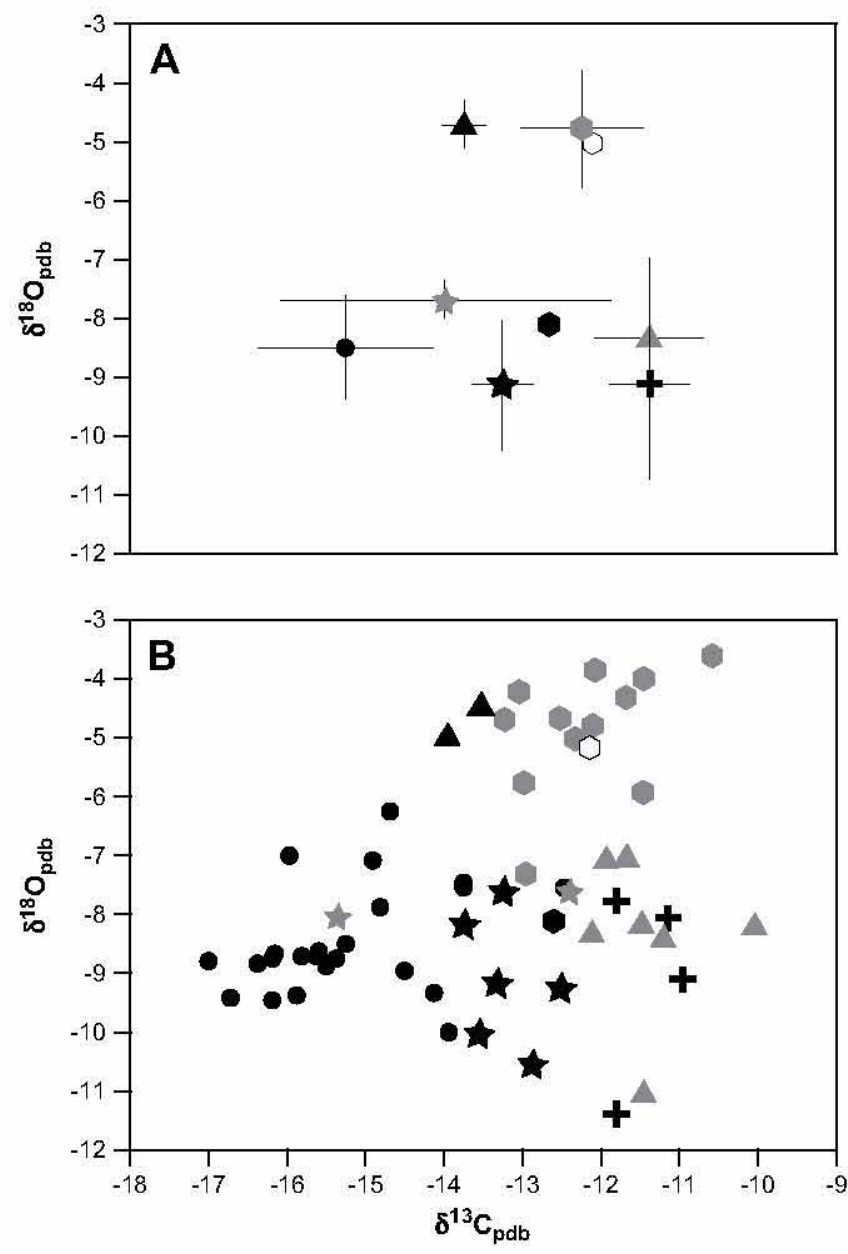

Cervus elaphus $\bigcirc$ Canis lupus $\$$ Lynx p. spelaeus
Dama dama $\bigcirc$ Cuon alpinus $\$$ Panthera leo cf. fossilis
+ Equus cabalius $\bigcirc$ vulpes vulpes $\bigcirc$ ursus deningen

Fig. 4. (A) Mean isotopic values from tooth enamel for species analyzed within this study. Lines represent one standard deviation from the mean. (B) Individual isotopic values.

$\delta^{18} \mathrm{O}$ value for the carnivores was $P$. leo with a value of $-9.2 \% \pm 1.1 \%$ o

\section{Discussion}

\subsection{Diagenetic evaluation}

$P$. leo occurs and was analyzed from the three localities (TG, TD and $\mathrm{SH}$ ), and similarly $V$. vulpes occurs and was sampled from TG and SH. While these localities likely had diverse depositional histories with fossil preservation taking place by different chemical processes, individuals of the same species had similar isotopic values. These data show that the enamel samples did not undergo diagenetic alteration, as the differences in preservational environment among the localities would likely have created differences in isotopic values. The data also support the idea of analyzing and comparing the ecology of species occurring within a particular faunal unit. Even though individuals may not have lived contemporaneously, species within ATA FU 6 appear to have maintained similar ecological relationships amongst themselves. 
Table 1

Stable carbon and oxygen isotope values of large mammal species from the late Pleistocene deposits of the Sierra de Atapuerca, northern Spain.

\begin{tabular}{|c|c|c|c|c|c|}
\hline Taxon & $N$ & $\begin{array}{l}\text { Mean } \delta^{13} \mathrm{C} \\
(\%)\end{array}$ & $\begin{array}{l}\delta^{13} \mathrm{C} \mathrm{SD} \\
(\%)\end{array}$ & $\begin{array}{l}\text { Mean } \delta^{18} \mathrm{O} \\
(\%)\end{array}$ & $\begin{array}{l}\delta^{18} \mathrm{OSD} \\
(\%)\end{array}$ \\
\hline Average for All Specimens & 58 & -13.5 & 1.8 & -7.6 & 1.9 \\
\hline \multicolumn{6}{|l|}{ Herbivores } \\
\hline \multicolumn{6}{|l|}{ Artiodactyla } \\
\hline \multicolumn{6}{|l|}{ Cervidae } \\
\hline Cervus elaphus priscus & 7 & -11.4 & 0.7 & -8.4 & 1.3 \\
\hline Dama dama clactoniana & 2 & -13.7 & 0.3 & -4.7 & 0.4 \\
\hline \multicolumn{6}{|l|}{ Equidae } \\
\hline Equus sp. (Caballine-type) & 4 & -11.4 & 0.5 & -9.1 & 1.7 \\
\hline \multicolumn{6}{|l|}{ Carnivores } \\
\hline \multicolumn{6}{|l|}{ Canidae } \\
\hline Canis lupus & 1 & -12.1 & - & -5.1 & - \\
\hline Cuon alpinus & 1 & -12.6 & - & -8.1 & - \\
\hline Vuipes vulpes & 12 & -12.2 & 0.8 & -4.8 & 1.0 \\
\hline \multicolumn{6}{|l|}{ Felidae } \\
\hline Lynxp. spelaeus & 2 & -13.9 & 2.1 & -7.9 & 0.3 \\
\hline Panthera leo $\mathrm{cf}$. fossilis & 6 & -13.2 & 0.4 & -9.2 & 1.1 \\
\hline \multicolumn{6}{|l|}{ Ursidae } \\
\hline Ursus deningeri & 23 & -15.2 & 1.1 & -8.5 & 0.9 \\
\hline
\end{tabular}

\subsection{Herbivore ecology}

Differences in resource use and physiology are implied by the statistically significant differences in isotopic values detected among the taxa. The isotopic results generally conform to predictions based on what is known about the ecology of $C$. elaphus and Equus sp. Cervus and Equus sp. mean $\delta^{13} \mathrm{C}$ values fall close together within the range expected for animals foraging in a light forest or grassland (Bocherens, 2003). The carbon isotope results for $C$. elaphus are not those expected from an indicator of closed forest at Pleistocene sites, as was suggested by some authors (Sommer and Nadachowski, 2006). Instead, the values obtained support the use of a more open, light forest or grassland environment for this cervid species. Although $C$. elaphus live mainly in forest areas and the adjacent surrounding fields today, it can also occupy open moorland (Staines et al., 1982). Similar to the results of Drucker et al. (2003), these results indicate that this species is likely more of a generalist capable of living and feeding in many different habitat types, and likely on many different forage types. The horse isotopic values match our predictions as a more generalist or mixed-feeder having values similar to $C$. elaphus.

Our predictions for carbon isotope values in $D$. dama, being indicative of more open habitats and $\delta^{13} \mathrm{C}$ values more positive than C. elaphus and Equus sp., are falsified. Our data for D. dama, being significantly more negative than the Equus sp. and C. elaphus data, indicate that the two D. dama individuals sampled inhabited or at least foraged in more closed habitat than either the sampled Equus sp. and C. elaphus populations. While grasses, sedges, and rushes are a dominant part of the diet of modern D. dama, other plants and plant parts, including fruit and even bark, can make up a significant portion $(>70 \%)$ of forage depending on where the population is located and what food is available at the time (Chapman and Chapman, 1975). These data show that D. dama was capable of living and eating in a wider variety of habitats than we expected. D. dama also differs from C. elaphus and Equus sp. in that it rarely drinks, obtaining most of its water from the vegetation it eats (Chapman and Chapman, 1975). The positive oxygen isotope values for $D$. dama conform to expectations for an animal that rarely drinks. Further, this ecology in D. dama (i.e., water from plant leaves) would support the idea of a Near East origin for the species, and its association with more arid Mediterranean environments.

\subsection{Carnivore ecology}

Similar to the herbivores, statistically significant differences were observed in carnivore $\delta^{13} \mathrm{C}$ values implying resource partitioning. $U$. deningeri differed from the rest of the carnivores. Taking into account the isotopic differences in the enamel of predator and prey (Fox-Dobbs et al., 2006), the $\delta^{13} \mathrm{C}$ values of all carnivores, except $U$. deningeri, fall among the range of $\delta^{13} \mathrm{C}$ values observed at these localities, and are typical of what is expected for predators that are not specialized on a particular species, but tend to be more generalized or opportunistic. Without sampling smaller mammals, suggesting preference for one prey type over another would be unwise.

While we are aware that certain cave bear populations may not have been obligate herbivores (Stiner et al., 1998; Richards et al., 2008), the negative $\delta^{13} \mathrm{C}$ values displayed by $U$. deningeri at Sima de los Huesos are similar to previous isotopic studies (Bocherens et al., 1991a, 1994), correspond to what has been proposed about their ecology from morphological analyses (García, 2003), and are suggestive of this population having an herbivorous diet. Physiologically, a long hibernation period with a strong contribution of lipids to metabolism, could also explain the low apatite $\delta^{13} \mathrm{C}$ values observed in Pleistocene bears relative to coeval carnivores and herbivores (Bocherens et al., 1994).

Examination of oxygen isotope values in the carnivores shows that $C$. lupus and $V$. vulpes had significantly more positive oxygen isotope values compared to the other carnivores at this locality. While we cannot currently pinpoint why the $\delta{ }^{18} \mathrm{O}$ values are significantly more positive in these two species, the differences may result from utilizing a different water source. For example, these two species could be using a different watering hole or obtaining most of their water from prey. The positive $\delta^{18} \mathrm{O}$ values could also be due to physiological differences compared to the other carnivores.

\subsection{Implications for prehistoric human diet}

Palaeodietary reconstruction using stable carbon and nitrogen isotope values from European Neanderthals has previously been analyzed from sites such as: Les Pradelles and Saint-Césaire I (France) (Bocherens et al., 1991b; Fizet et al., 1995; Bocherens and Drucker, 2003; Drucker and Bocherens, 2004), Scladina and Spy (Belgium) (Bocherens et al., 1999, 2001), Vindija (Slovenia) (Richards et al., 2000). Each of these investigations has suggested that the values of Neanderthals were similar to those of contemporary predators indicating that their diet was generally dominated by the meat of large herbivores. The results obtained within the present study provide a good framework in which to place ancient humans. In this context, based on these previous Neanderthal studies, we suspect that the dietary habits of the pre-Neanderthals ( $H$. heidelbergensis) discovered in the Sima de los Huesos that lived during the Middle Pleistocene already had a trophic position similar to those of contemporary large predators, such as lions. We predict that future isotope analysis of this population would show values similar to the other large carnivores at the site.

\subsection{Comparison with other Pleistocene sites}

Comparison of the isotope data presented here from the Sierra de Atapuerca to other similarly sampled Pleistocene localities, such as Kent's Cavern, England (Bocherens et al., 1995), Marillac, France (Fizet et al., 1995), Paglicci Cave, Italy (Iacumin et al., 1997), Scladina Cave, Belgium (Bocherens et al., 1997), and Venta Micena, Spain (Pamlqvist et al., 2003, 2008), does not reveal overall generalities among the fauna in their resource use. However, it appears that 
faunal relationships are dependent at least on geographic location as well as what particular species are present. Our results appear most similar to the results found at the Upper Pleistocene Kent's Cavern, England (Bocherens et al., 1995) than any of the other mentioned localities. While the exact same taxa were not present or sampled between Kent's Cavern and the Sierra de Atapuerca sites, both show that horses and cervids have $\delta^{13} \mathrm{C}$ values near the most positive in the fauna, large carnivores display intermediate carbon isotope values, and bears show the most negative values. These results in comparing the faunas are interesting in that they show species' ability to interact differently when among various fauna at the different localities.

This study shows that isotopic analyses do not necessarily require ecosystems with $C_{3}$ and $C_{4}$ plants or the analyses of nitrogen isotopes (i.e. collagen) to be informative. Isotopic analysis of enamel apatite in $\mathrm{C}_{3}$-dominated ancient ecosystems provides more detailed information about ancient human and faunal dietary habits, and the possible role of dietary changes during climatic oscillations. With the addition of more species, especially smaller mammals, we can obtain an even more complete understanding of the ecological setting in which humans lived and analyses over time will allow an understanding of how the environment and the ecology of species within the Sierra de Atapuerca, including humans, evolved over the last million years of the Pleistocene.

\section{Conclusions}

Significant differences in stable isotope values obtained from the tooth enamel of large carnivores and herbivores from the Middle Pleistocene in the Sierra de Atapuerca imply differences in resource use. The isotopic results generally conform to ecology indicated by other techniques in previous analyses. For the herbivores sampled, isotopic values support C. elaphus and Equus sp. as being mixed-feeders in a light forest or grassland, and $D$. dama foraging in more forested habitats.

For the carnivores, isotopic values are more negative in $U$. deningeri than the other sampled carnivores. We suspect that these negative values are either due to herbivory or effects from hibernation. The data for rest of the carnivores suggest the predators to be capable of feeding on a variety of prey and not specialized on a particular species. This technique provides another methodology to assess ecology of taxa and accurately portray the setting in which humans lived. Future analyses may allow an understanding of the evolution of ecology within the Sierra de Atapuerca over the last half of the Pleistocene.

\section{Acknowledgements}

N.G. was a postdoctoral fellow at the Human Evolution Research Center (University of California - Berkeley), under the direction of C. Howell and T. White, when the analyses were being conducted. They wholeheartedly supported this project and financed the analyses. We are also grateful to T. Barnosky (UC Berkeley), the Department of Integrative Biology at UC Berkeley, as well as the Sierra de Atapuerca excavation team. We thank H. Bocherens and an anonymous reviewer for comments and suggestions that improved the manuscript. We further thank the Ministerio de Ciencia y Tecnología and the New York State Museum who provided logistical support.

\section{Appendix. Supplementary data}

Supplementary data associated with this article can be found, in the online version, at doi:10.1016/j.jas.2008.12.018.

\section{References}

Apollonio, M., Focardi, S., Toso, S., Nacci, L., 1998. Habitat selection and group formation pattern of Fallow deer Dama dama in a submediterranean environment. Ecography 21 (3), 225-234.

Arsuaga, J.L., Martínez, I., Gracia, A., Carretero, J.M., Carbonell, E., 1993. Three new human skulls from the Sima de los Huesos Middle Pleistocene site in Sierra de Atapuerca, Spain. Nature 362, 534-537.

Arsuaga, J.L., Martínez, I., Gracia, A., 2001. Analyse phylogénétique des Hominidés de la Sierra de Atapuerca (Sima de los Huesos et Gran Dolina TD-6): l'évidence crânienne. L'Anthropologie 105, 161-178.

Barkai, R, Gopher, S.E., Lauritzen, S.E., Frumkin, A., 2003. The end of the lower Paleolithic in the Levant: U-series dates from Quesem Cave, Israel. Nature 423 , 977-979.

Berger, G.W., Perez-Gonzalez, A., Carbonell, E., Arsuaga, J.L., Bermudez de Castro, J.M., Ku, T.K., 2008. Luminescence chronology of cave sediments at the Atapuerca paleoanthropological site, Spain. Journal of Human Evolution 55, 300-311.

Bermúdez de Castro, J.M., Arsuaga, J.L., Carbonell, E., Rosas, A., Martínez, I., Mosquera, M., 1997. A hominid from the Lower Pleistocene of Atapuerca, Spain: possible ancestor to Neandertals and modern humans. Science 276, 1392-1395.

Bischoff, J.L., Williams, R.W., Rosenbauer, RJ., Aranburu, A., Arsuaga, J.L., García, N., Cuenca-Bescós, G., 2007. High-resolution U-series dates from the Sima de los Huesos yields $600+\infty-66$ kyrs: implications for the evolution of the Neanderthal lineage. Journal of Archaeological Science 34, 763-770.

Bocherens, H., 2000. Preservation of isotopic signals $\left({ }^{13} \mathrm{C},{ }^{15} \mathrm{~N}\right)$ in Pleistocene mammals. In: Katzenberg, M.A., Ambrose, S.H. (Eds.), Biogeochemical Approaches to Paleodietary Analyses. Kluwer Academic/Plenum Publishers, New York, pp. 65-88.

Bocherens, H., 2003. Isotopic biogeochemistry and the paleoecology of the mammoth steppe fauna. Deinsea 9, 57-76.

Bocherens, H., Argant, A., Argant, J., Billiou, D., Cregut-Bonnoure, E., DonatAyache, B., Philippe, M., Thinon, M., 2004. Diet reconstruction of ancient brown bears (Ursus arctos) from Mont Ventoux (France) using bone collagen stable isotope biogeochemistry. Canadian Journal of Zoology 82, 576-586.

Bocherens, H., Billiou, D., Mariotti, A., Toussaint, M., Patou-Mathis, M., Bonjean, D., Otte, M., 2001. New isotopic evidence for dietary habits of Neandertals from Belgium. Journal of Human Evolution 40, 497-505.

Bocherens, H., Billiou, D., Patou-Mathis, M., Bonjean, D., Otte, M., Mariotti, A., 1997. Paleobiological implications of the isotopic signatures $\left({ }^{13} \mathrm{C},{ }^{15} \mathrm{~N}\right)$ of fossil mammal collagen in Scladina Cave (Sclayn, Belgium). Quaternary Research 48 , $370-380$.

Bocherens, H., Billiou, D., Patou-Mathis, M., Otte, M., Bonjean, D., Toussaint, M. Mariotti, A., 1999. Palaeoenvironmental and palaeodietary implications of isotopic biogeochemistry of late interglacial Neandertal and mammal bones in Scladina Cave (Belgium). Journal of Archaeological Science 26, 599-607.

Bocherens, H., Drucker, D., 2003. Trophic level isotopic enrichment of carbon and nitrogen in bone collagen: case studies from recent and ancient terrestrial ecosystems. International Journal of Osteoarchaeology 13, 46-53.

Bocherens, H., Fizet, M., Mariotti, A., 1994. Diet, physiology and ecology of fossil mammals as inferred from stable carbon and nitrogen isotope biogeochemistry: implications for Pleistocene bears. Palaeogeography, Palaeoclimatology, Palaeoecology 107, 213-225.

Bocherens, H., Fizet, M., Mariotti, A., Billiou, D., Bellon, G., Borel, J.-P., Simone, S., 1991a. Biogéochimie isotopique $\left({ }^{13} \mathrm{C},{ }^{15} \mathrm{~N},{ }^{18} \mathrm{O}\right)$ et Paléoécologie des ours pléistocènes de la grotte d'Aldène (Cesseras, Hérault). Bulletin du Musée d'Anthropologie et de Préhistoire, Monaco 31, 29-49.

Bocherens, H., Fizet, M., Mariotti, A., Lange-Badre, B., Vandermeersch, B., Borel, J.P. Bellon, G., 1991b. Isotopic biogeochemistry $\left({ }^{13} \mathrm{C},{ }^{15} \mathrm{~N}\right)$ of fossil vertebrate collagen: application to the study of a past food web including Neandertal man. Journal of Human Evolution 20, 481-492.

Bocherens, H., Fogel, M.L., Tuross, N., Zeder, M., 1995. Trophic structure and climatic information from isotopic signatures in Pleistocene cave fauna of Southern England. Journal of Archaeological Science 22, 327-340.

Bocherens, H., Koch, P.L., Mariotti, A., Geraads, D., Jaeger, J.-I., 1996. Isotopic biogeochemistry $\left({ }^{13} \mathrm{C},{ }^{18} \mathrm{O}\right)$ of mammalian enamel from African Pleistocene hominid sites. Palaios 11, 306-318.

Bryant, J.D., Froelich, P.N., 1995. A model of oxygen isotope fractionation in body water of large mammals. Geochimica et Cosmochimica Acta 59, 4523-4537.

Carbonell, E., Bermúdez De Castro, J.M., Arsuaga, J.L., Díez, J.C., Rosas, A., CuencaBescós, G., Sala, R, Mosquera, M., Rodríguez, X.P., 1995. Lower Pleistocene hominids and artefacts from Atapuerca-TD6 (Spain). Science 269, 826-830.

Carbonell, E., Mosquera, M., Ollé, A., Rodríguez, X.-P., Sahnouni, M., Sala, R., Vergès, J.M., 2001. Structure morphotechnique de l'industrie lithique du Pléistocène infërieur et moyen d'Atapuerca (Burgos, Espagne). L'Anthropologie 105, $259-280$.

Cerling, T.E., Harris, J.M., 1999. Carbon isotope fractionation between diet and bioapatite in ungulate mammals and implications for ecological and paleoecological studies. Oecologia 120, 347-363.

Cerling, T.E., Harris, J.M., Ambrose, S.H., Leakey, M.G., Solounias, N., 1997. Dietary and environmental reconstruction with stable isotope analyses of herbivore tooth enamel from the Miocene locality of Fort Ternan, Kenya. Journal of Human Evolution 33, 635-650.

Cerling, T.E., Harris, J.M., Leakey, M.G., 1999. Browsing and grazing in elephants: the isotope record of modern and fossil proboscideans. Oecologia 120, 364-374. 
Cerling, T.E., Harris, J.M., MacFadden, B.J., 1998. Carbon isotopes, diets of North American equids, and the evolution of North American C4 grasslands. In: Griffiths, $\mathrm{H}$ (Ed.), Stable Isotopes. BIOS Scientific Publishers Ltd., Oxford, pp. 363-379.

Cerling, T.E., Hart, J.A., Hart, T.B., 2004. Stable isotope ecology in the Ituri Forest. Oecologia 138, 5-12.

Chapman, D., Chapman, N., 1975. Fallow Deer: Their History, Distribution, and Biology. The Lavenham Press Limited, Lavenham, Great Britain.

Cohen, J.A., 1978. Cuon alpinus. Mammalian Species 100, 1-3.

Collins, R.P. Jones, M.B., 1985. The influence of climatic factors on the distribution of $\mathrm{C}_{4}$ species in Europe. Vegetatio 64, 121-129.

Coltorti, M., Feraud, G., Peretto, C., Ton-Thate, T., Voinchetf, P., Bahain, J.-J., Minelli, A., Thun Hohensteind, U., 2005. New 40Ar/39Ar, stratigraphic and palaeoclimatic data on the Isernia La Pineta Lower Palaeolithic site, Molise, Italy. Quaternary International 131, 11-22.

Cuenca-Bescós, G., Canudo, J.I., Laplana, C., 2001. La sequence des rongeurs (Mammalia) des sites du Pleistocene inferieur et moyen d'Atapuerca (Burgos, Espagne). L'Anthropologie 105, 115-130.

Cuenca-Bescós, G., Conesa, C.L, 1997. Small mammals from the Sima de los Huesos. Journal of Human Evolution 33, 175-190.

Cuenca-Bescós, G., García, N., 2007. Biostratigraphic succession of the Early and Middle Pleistocene mammal faunas of the Atapuerca cave sites (Spain, Southwestern Europe). Courier Forschungsinstitut Senckenberg; Frankfurt a. M. In: Kahlke, R.-D., Maul, L.C., Mazza, P. (Eds.), Late Neogene and Quaternary Biodiversity and Evolution: Regional Developments and Interregional Correlations, Vol. 259, pp. 101-112.

Dansgaard, W., Clausen, H.B., Gundestrup, N., Hammer, C.U., Johnson, S.F., Kristinsdottir, P.M., Reeh, N., 1982. A new Greenland deep ice core. Science 218, 1273-1277.

DeNiro, M.J., Epstein, S., 1978a. Carbon isotopic evidence for different feeding patterns in two hyrax species occupying the same habitat Science 201, 906-908.

DeNiro, M.J., Epstein, S., 1978b. Influence of diet on the distribution of carbon isotopes in animals. Geochimica et Cosmochimica Acta 42, 495-506.

Drucker, D., Bocherens, H., 2004. Carbon and nitrogen stable isotopes as tracers of change in diet breadth during Middle and Upper Palaeolithic in Europe. International Journal of Osteoarchaeology 14, 162-177.

Drucker, D., Bocherens, H., Bridault, A., Billiou, D., 2003. Carbon and nitrogen isotopic composition of Red deer (Cervus elaphus) collagen as a tool for tracking palaeoenvironmental change during the Late-Glacial and Early Holocene in the northern Jura (France). Palaeogeography, Palaeoclimatology, Palaeoecology 195, 375-388.

Ehleringer, J.R., Monson, R.K., 1993. Evolutionary and ecological aspects of photosynthetic pathway variation. Annual Review of Ecology and Systematics 24 , 411-439.

Ehleringer, J.R., Sage, R.F., Flanagan, LB, Pearcy, R.W, 1991. Climate change and the evolution of C4 photosynthesis. Trends in Ecology and Evolution 6, 95-99.

Erdbrink, D.P., 1953. A Review of Fossil and Recent Bears of the Old World - With Remarks on Their Phylogeny-Based Upon Their Dentition. Ph.D. dissertation, Utrecht University.

Falguères, C., Bahain, J.-J., Yokoyama, Y., Arsuaga, J.L, Bermudez de Castro, J.M., Carbonell, E., Bischoff, J.L., Dolo, J.-M., 1999. Earliest humans in Europe: the age of TD6 Gran Dolina, Atapuerca, Spain. Journal of Human Evolution 37, 343-352.

Farquhar, G.D., Ehleringer, J.R., Hubick, K.T., 1989. Carbon isotope discrimination and photosynthesis. Annual Review of Plant Physiology and Plant Molecular Biology $40,503-537$.

Feranec, R.S., MacFadden, B.J., 2006. Isotopic discrimination of resource partitioning among ungulates in $\mathrm{C}_{3}$-dominated communities from the Miocene of Florida and California. Paleobiology 32, 191-205.

Fizet, M., Mariotti, A., Bocherens, H., Lange-Badré, B., Vandermeersch, B., Borel, J.P., Bellon, G., 1995. Effect of diet, physiology and climate on carbon and nitrogen stable isotopes of collagen in a late Pleistocene anthropic palaeoecosystem: Marillac, Charente, France. Journal of Archaeological Science 22, 67-79.

Flynn, J.J., MacFadden, B.J., McKenna, M.C., 1984. Land-mammal ages, faunal heterochrony, and temporal resolution in Cenozoic terrestrial sequences. Journal of Geology 92, 687-705.

Fox-Dobbs, K., Wheatley, P.V., Koch, P.L, 2006. Carnivore specific bone bioapatite and collagen carbon isotope fractionations: case studies of modern and fossil grey wolf populations. Eos Trans. AGU 87, Fall Meet. Suppl., B53C-0366.

Fricke, H.C., O'Neil, J.R., 1996. Inter- and intra-tooth variation in the oxygen isotope composition of mammalian tooth enamel phosphate: implications for palaeoclimatological and palaeobiological research. Palaeogeography, Palaeoclimatology, Palaeoecology 126, 91-99.

Friedli, H., Lotscher, H., Oeschger, H., Siegenthaler, U., Stauffer, B., 1986. Ice core record of the $13 \mathrm{C} / 12 \mathrm{C}$ ratio of atmospheric $\mathrm{CO}_{2}$ in the past two centuries. Nature 324, 237-238.

García, N., 2003. Osos y otros carnívoros de la Sierra de Atapuerca. Fundación Oso Asturias, Oviedo.

García, N., Arsuaga, J.L., 1998. The carnivore remains from the hominid-bearing Trinchera-Galería, Sierra de Atapuerca, Middle Pleistocene site (Spain). Geobios $31,659-674$.

García, N., Arsuaga, J.L., 1999. Carnivores from the Early Pleistocene hominidbearing Trinchera Dolina 6 (Sierra de Atapuerca, Spain). Journal of Human Evolution 37, 415-430.

García, N., Arsuaga, J.L., 2001a. Ursus dolinensis: a new species of Early Pleistocene ursid from Trinchera Dolina, Atapuerca (Spain). Comptes Rendus de l'Académie des Sciences Paris, Earth and Planetary Sciences 332, 717-725. ancien et moyen d'Atapuerca (Espagne). L'Anthropologie 105, 83-93.

arcía, N., Arsuaga, J.L., Torres, T., 1997. The carnivore remains from the Sima de los Huesos Middle Pleistocene site (Sierra de Atapuerca, Spain). Journal of Human Evolution 33, 155-174

García, N., Virgós, E., 2007. Evolution of community composition in several carnivore palaeoguilds from the European Pleistocene: the role of interspecific competition. Lethaia $40,33-44$.

García-González, R., Cuartas, P., 1992. Food habits of Capra pyrenaica, Cervus elaphus, and Dama dama in the Cazorla Sierra, Spain. Mammalia 56, 195-202.

Gebert, C, Verheyden-Tixier, 2001. Variations of diet composition of Red deer (Cervus elaphus L) in Europe. Mammal Review 31 (3-4), 189-201.

Geist, V., 1999. Deer of the World. Their Evolution, Behaviour and Ecology. Swan Hill Press, p. 3.

Grocke, D.R., 1997. Stable-isotope studies on the collagenic and hydroxylapatite components of fossils: palaeoecological implications. Lethaia 30 $65-78$

Haas, S.K., Hayssen, V., Krausman, P.R., 2005. Panthera leo. Mammalian Species 762 , $1-11$.

Heaton, T.H.E., 1999. Spatial, species, and temporal variations in the $13 \mathrm{C} / 12 \mathrm{C}$ ratios of C3 plants: implications for paleodiet study. Journal of Archaeological Science $26,637-649$.

Hofmann, RR, 1985. Digestive physiology of the deer-their morphophysiological specialization and adaptation. The Royal Society of New Zealand Bulletin 22 , $393-407$.

Hofmann, R.R, 1989. Evolutionary steps of ecophysiological adaptation and diversification of ruminants: comparative view of their digestive system. Oecologia $78,443-457$.

Iacumin, P., Bocherens, H., Delgado Huertas, A., Mariotti, A., Longinelli, A., 1997. A stable isotope study of fossil mammal remains from the Paglicci Cave, Southern Italy. $\mathrm{N}$ and $\mathrm{C}$ as palaeoenvironmental indicators. Earth and Planetary Science Letters 148, 349-357.

Janis, C.M., Ehrhardt, D., 1988. Correlation of relative muzzle width and relative incisor width with dietary preference. Biological Journal of the Linnean Society $92,267-284$

Kaiser, T.M., Franz-Odendaal, T.A., 2004. A mixed-feeding Equus species from the Middle Pleistocene of South Africa. Quaternary Research 62, 316-323.

Koch, P.L, 1998. Isotopic reconstruction of past continental environments. Annual Review of Earth and Planetary Science 26, 573-613.

Koch, P.L, Fisher, D.C., Dettman, D., 1989. Oxygen isotope variation in the tusks of extinct proboscideans: a measure of season of death and seasonality. Geology $17,515-519$.

Koch, P.L, Hoppe, K.A., Webb, S.D., 1998. The isotopic ecology of late Pleistocene mammals in North America Part 1. Florida. Chemical Geology 152 $119-138$

Koch, P.L., Tuross, N., Fogel, M.L, 1997. The effects of sample treatment and diagenesis on the isotopic integrity of carbonate in biogenic hydroxylapatite Journal of Archaeological Science 24, 417-429.

Kohn, M.J., 1996. Predicting animal $\delta^{18} \mathrm{O}$ : accounting for diet and physiological adaptation. Geochimica et Cosmochimica Acta 60, 4811-4829.

Kohn, M.J., McKay, M.P., Knight, J.L., 2005. Dining in the Pleistocene-who's on the menu? Geology 33, 649-652

Kohn, M.J., Schoeninger, M.J., Valley, J.W., 1996. Herbivore tooth oxygen isotope compositions: effect of diet and physiology. Geochimica et Cosmochimica Acta $60,3889-3896$

Kohn, M.J., Schoeninger, M.J., Valley, J.W., 1998. Variability on oxygen isotope compositions of herbivore teeth: reflections of seasonality or developmental physiology. Chemical Geology 152, 97-112.

Kohn, M.J., Welker, J.M., 2005. On the temperature correlation of $\delta^{18} \mathrm{O}$ in modern precipitation. Earth and Planetary Science Letters 231, 87-96.

Kurtén, B., 1968. Pleistocene Mammals of Europe. Weidenfeld \& Nicholson, London

Land, L.S., Lundelius, E.L, Valastro, S., 1980. Isotopic ecology of deer bones. Palaeogeography, Palaeoclimatology, Palaeoecology 32, 143-151.

Lariviere, S., Pasitschniak-Arts, M., 1996. Vulpes vulpes. Mammalian Species 537 $1-11$.

Lariviere, S., Walton, L. R., 1997. Lynx rufus. Mammalian Species 563, 1-8.

Lee-Thorp, J.A., Thackeray, J.F., van der Merwe, N.A., 2000. The hunters and the hunted revisited. Journal of Human Evolution 39, 565-576.

Leonardi, G., Petronio, C., 1976. The Fallow deer of European Pleistocene. Geologica Romana 15, 1-67.

Linhart, S.B., 1968. Dentition and pelage in the juvenile red fox (Vuipes vuipes). Journal of Mammalogy 49, 526-528.

Longinelli, A., 1984. Oxygen isotopes in mammal bone phosphate: a new tool for paleohydrological and paleoclimatological research? Geochimica et Cosmochimica Acta $48,385-390$.

López Antoñanzas, R. Cuenca-Bescós, G, 2002. The Gran Dolina Site (Lower to Middle Pleistocene, Atapuerca, Burgos, Spain): new palaeoenvironmental data based on the distribution of small mammals. Palaeogeography, Palaeoclimatology, Palaeoecology 186, 311-334

Luz, B., Kolodny, Y., 1985. Oxygen isotope variations in phosphate of biogenic apatites, IV. Mammal teeth and bones. Earth and Planetary Science Letters 75 29-36.

Luz, B., Kolodny, Y., Horowitz, M., 1984. Fractionation of oxygen isotopes between mammalian bone-phosphate and environmental drinking water. Geochimica et Cosmochimica Acta 48, 1689-1693. 
MacFadden, B.J., Cerling, T.E., 1996. Mammalian herbivore communities, ancient feeding ecology, and carbon isotopes; a 10 million-year sequence from the Neogene of Florida. Journal of Vertebrate Paleontology 16, 103-115.

MacFadden, B.J., Solounias, N., Cerling, T.E., 1999. Ancient diets, ecology, and extinction of 5 million-year-old horses from Florida. Science 283, 824-827.

Marino, B.D., McElroy, M.B., 1991. Isotopic composition of atmospheric $\mathrm{CO}_{2}$ inferred from carbon in C4 plant cellulose. Nature 349, 127-131

Marino, B.D., McElroy, M.B., Salawitch, R.J., Spaulding, W.G., 1992. Glacial-to-interglacial variations in the carbon isotopic composition of atmospheric $\mathrm{CO}_{2}$. Nature $357,461-466$

Martínez Martínez, T., 2002. Comparison and overlap of sympatric wild Cazorla Segura and Las Villas natural park. Pirineos 157, 103-115.

Mazza, P., Rustioni, M., 1994. On the phylogeny of Eurasian bears. Palaeontographica. Abteilung A, Palaeozoologie, Stratigraphie 230, 1-38.

Mazza, P., Rustioni, M., Boscagli, G., 1995. Evolution of ursid dentition, with inferences on the functional morphology of the masticatory apparatus in the genus Ursus. In: Moggi-Cecchi, J. (Ed.), Aspects of Dental Biology: Paleontology Anthropology and Evolution. International Institute for the Study of Man Florence, pp. 147-157.

Mech, L.D., 1974. Canis lupus. Mammalian Species 37, 1-6.

Nelson, D.E., Angerbjorn, A., Liden, K., Turk, I., 1998. Stable isotopes and the metabolism of the European cave bear. Oecologia 116, 177-181

O'Leary, M.H., 1988. Carbon isotopes in photosynthesis. Bioscience 38, 328-336.

O'Leary, M.H., Madhavan, S., Paneth, P., 1992. Physical and chemical basis of carbon isotope fractionation in plants. Plant, Cell and Environment 15, 1099-1104

Ometto, J.P.H., Flanagan, L.B., Martinelli, L.A., Ehleringer, J.R., 2005. Oxygen isotope ratios of waters and respired $\mathrm{CO}_{2}$ in Amazonian forest and pasture ecosystems. Ecological Applications 15, 58-70.

Pamlqvist, P., Grocke, D.R., Arribas, A., Farina, R.A., 2003. Paleoecological reconstruction of a lower Pleistocene large mammal community using biogeochemical $\left(\delta^{13} \mathrm{C}, \quad \delta^{15} \mathrm{~N}, \quad \delta^{18} \mathrm{O}, \quad \mathrm{Sr}: \mathrm{Zn}\right)$ and ecomorphological approaches. Paleobiology 29, 205-229.

Pamlqvist, P., Perez-Claros, J.A., Janis, C.M., Grocke, D.R., 2008. Tracing the ecophysiology of ungulates and predator-prey relationships in an early Pleistocene large mammal community. Palaeogeography, Palaeoclimatology, Palaeoecology $266,95-111$

Passey, B.H., Robinson, T.F., Ayliffe, L.K., Cerling, T.E., Sponheimer, M., Dearing, M.-D., Roeder, B.L., Ehleringer, J.R., 2005. Carbon isotope fractionation between diet breath $\mathrm{CO}_{2}$, and bioapatite in different mammals. Journal of Archaeological Science 32, 1459-1470.

Putnam, R., 1988. The Natural History of Deer. Comstock Publishing, Cornel University Press, Ithaca, NY

Quade, J., Cerling, T.E., 1995. Expansion of $C_{4}$ grasses in the late Miocene of northern Pakistan: evidence form stable isotopes in paleosols. Palaeogeography, Palaeoclimatology, Palaeoecology 115, 91-116

Quade, J., Cerling, T.E., Barry, J.C., Morgan, M.E., Pilbeam, D.R., Chivas, A.R, LeeThorp, J.A., van der Merwe, N.A., 1992. A 16-Ma record of paleodiet using carbon and oxygen isotopes in fossil teeth from Pakistan. Chemical Geology 94 183-192.

Richards, M.P., Pettitt, P.B., Trinkaus, E., Smith, F.H., Paunovic, M., Karavanic, I., 2000 Neandertal diet at Vindija and Neandertal predation: the evidence from stable isotopes. Proceedings of the National Academy of Sciences of the United States of America 97, 7663-7666.

Richards, M.P., Pacher, M., Stiller, M., Quiles, J., Hofreiter, M., Constantin, S., Zilhao, J., Trinkhaus, E., 2008. Isotopic evidence for omnivory among European cave bears: Late Pleistocene Ursus spelaeus from Pestera cu Oase, Romania. Proceedings of the National Academy of Sciences of the United States of America 105, 600-604.

Rodríguez, J., 1997. Paleoecología del Pleistoceno de Atapuerca. Ph.D. dissertation Universidad Autónoma de Madrid, Madrid.

Rozanski, K., Araguas-Araguas, L., Gonfiantini, R., 1992. Relation between long-term trends of oxygen-18 isotope composition of precipitation and climate. Science 258, 981-985.
Sage, R.F., Wedin, D.A., Li, M., 1999. The biogeography of C4 photosynthesis: patterns and controlling factors. In: Sage, R.F., Monson, R.K. (Eds.), C 4 Plant Biology. Academic Press, New York, pp. 313-373.

Slaughter, B.H., Pine, R.H., Pine, N.E., 1974. Eruption of cheek teeth in Insectivora and Carnivora. Journal of Mammalogy 55, 115-125.

Smuts, G.L., Anderson, J.L., Austin, J.C., 1978. Age determination of the African lion (Panthera leo). Journal of Zoology 185, 115-146.

Soergel, W., 1926. Der Bär von Süssenborn. Ein Beitrag zur näheren Kenntnis der diluvialen Bären. In: Neues Jahrbuch fürr Mineralogie, Geologie und Paläontologie, 19, Beilage Band, Abteilung B (Geol. u. Paläontol.), pp. 115-156, Taf. III-XIV, 3 Textfig Stuttgart.

Sommer, R.S., Nadachowski, A., 2006. Glacial refugia of mammals in Europe: evidence from fossil records. Mammal Review 36, 251-265.

Staines, B.W., Crisp, J.M., Parish, T., 1982. Differences in the quality of food eaten by Red deer (Cervus elaphus) stags and hinds in winter. Journal of Applied Ecology $19,65-77$

Stevens, R.E., Hedges, R.E.M., 2004. Carbon and nitrogen stable isotope analysis of northwest European horse bones and tooth collagen, 40,000 BP-present: palaeoclimatic interpretations. Quaternary Science Reviews 23, 977-991.

Stiner, M.C., Achyuthan, H., Arsebuk, G., Howell, F.C., Josephson, S.C., Juell, K.E., Pigati, J., Quade, J., 1998. Reconstructing cave bear paleoecology from skeletons: a cross-disciplinary study of middle Pleistocene bears from Yarimburgaz Cave, Turkey. Paleobiology 24, 74-98.

Thenius, E., 1965. Die Carnivoren-reste aus dem Altpleistozän von Voigsted bei Sangerhausen in Thuringen. Palaeontographica Abteilung 11, 537-564.

Tieszen, L.L., 1994. Stable isotopes on the plains: vegetation analyses and diet determinations. In: Owsley, D.W., Jantz, R.L. (Eds.), Skeletal Biology in the Great Plains: Migration, Warfare, Health, and Subsistence. Smithsonian Institution Press, Washington, DC.

Tieszen, L.L., Hein, D., Qvortrup, S.A., Troughton, J.H., Imbamba, S.K., 1979. Use of $\delta^{13} \mathrm{C}$ values to determine vegetation selectivity in East African herbivores. Oecologia 37, 351-359.

Torres, T., 1984. Úrsidos del Pleistoceno-Holoceno de la Península Ibérica. Ph.D. dissertation, Universidad Politécnica de Madrid, Madrid.

Tsoukala E., 1989. Contribution to the study of the Pleistocene fauna of large mammals (Carnivora, Perissodactyla, Artyodactila) from Petralona Cave (Chalkidiki, N. Greece). Ph.D. thesis, Aristotle University of Thessaloniki, Sci. Ann., School of Geology 1, 1-360, 124 fig., 64 tabl., 62. pl. (in Greek, with summary in English). C.R.A.S. Paris, 1991, 312(II), 331-336 (preliminary report).

Tumlison, R, 1987. Felix lynx. Mammalian Species 269, 1-8.

Valdiosera, C., García, N., Dalén, L, Smith, C., Kahlke, R.-D., Lidén, K. Angerbjörn, A., Arsuaga, J.L., Götherström, A., 2006. Typing single polymorphic nucleotides in mitochondrial DNA as a way to access Middle Pleistocene DNA. Biology Letters 2, 601-603.

van der Made, J., 1999. Ungulates from Atapuerca TD6. Journal of Human Evolution $37,389-413$

van der Made, J., 2001. Les Ongules d'Atapuerca. Stratigraphie et biogeographie. L'Anthropologie 105, 95-113.

van der Made, J., Aguirre, E., Bastir, M., Fernández Jalvo, Y., Huguet, R., Laplana, C., Marquez, B., Martínez, C., Martinón, M., Rosas, A., Rodríguez, J., Sánchez, A. Sarmiento, S., Bermúdez de Castro, J.M., 2003. El registro paleontológico y arqueológico de los yacimientos de la Trinchera del Ferrocarril en la Sierra de Atapuerca. Coloquios de Paleontología 1, 345-372.

van der Merwe, N.A., Medina, E., 1991. The canopy effect, carbon isotope ratios and foodwebs in Amazonia. Journal of Archaeological Science 18, 249-259.

Vogel, J.C., 1978. Isotopic assessment of the dietary habits of ungulates. South African Journal of Science 74, 298-301.

Yakir, D., 1992. Variations in the natural abundance of oxygen-18 and deuterium in plant carbohydrates. Plant, Cell and Environment 15, 1005-1020.

Yakir, D., DeNiro, M.J., Gat, J.R., 1990. Natural deuterium and oxygen-18 enrichment in leaf water of cotton plants grown under wet and dry conditions: evidence for water compartmentation and its dynamics. Plant, Cell and Environment 13, $49-56$. 